\title{
ONTOLOGICZNE PODSTAWY ANTROPOLOGII BL. ANTONIA ROSMINIEGO
}

\begin{abstract}
Wstęp
Jedna z najpopularniejszych biografii bł. Antonia Rosminiego (1797-1855) nosi znamienny tytuł Il santo proibito, czyli Zakazany święty ${ }^{1}$. Związane jest to z niecodziennymi zawiłościami życiorysu błogosławionego kapłana ze Stresy - włoskiego intelektualisty, teologa, filozofa, teoretyka prawa, politologa, poety, duszpasterza, zakonodawcy, pedagoga. Powyższa lista zawiera tylko najważniejsze obszary działalności intelektualnej włoskiego kapłana, o którym jeden z najważniejszych przedstawicieli włoskiego romantyzmu, pisarz Alessandro Manzoni, miał powiedzieć, że Rosmini ,jest jednym z sześciu lub siedmiu największych umysłów, jakimi może się poszczycić rodzaj ludzki"”. Bibliografia filozofa z Rovereto obejmuje około 100 pozycji, przeważnie bardzo obszernych, składających się z kilku tomów, z których każdy liczy kilkaset stron.

Mimo niezrozumienia i niejednokrotnie niezasłużonej krytyki ze strony ludzi Kościoła Rosmini pozostał wiernym jego synem. Kilku papieży ceniło jego dokonania intelektualne do tego stopnia, że Pius IX obiecał mu kapelusz kardynalski Jednak ludzie nieprzychylni Rosminiemu nominację tę zablokowali i doprowadzili do wpisania w 1849 r. na Indeks ksiag zakazanych dwóch jego dzieł: O pięciu ranach Kościoła świętego (Delle cinque piaghe della santa Chiesa) i Konstytucji wedtug sprawiedliwości społecznej (La Costituzione secondo la giustizia sociale). Ósmego listopada 2007 r., po blisko 160 latach od wydania drukiem pierwszej z wymienionych książek, Rosmini został ogłoszony w Novarze błogosławionym Kościoła katolickiego. W dziejach Watykanu jest to wydarzeni zupełnie bez precedensu. W historii zdarzały się błędne czy też tendencyjne oceny dokonań niektórych teologów. Jednak żaden z nich nie przeszedł rosminiańskiego szlaku od Indeksu do chwały ołtarzy.

Pośród różnorodnych dziedzin, jakimi zajmował się włoski myśliciel, główne miejsce zajmowała filozofia, a szczególnie etyka i antropologia. Nie bez powodu jest
\end{abstract}

1 M. Dossi, Il santo proibito. La vita e il pensiero di Antonio Rosmini, Trento 2017.

2 U. Muratore, Manzoni e Rosmini: le ragioni di un'amicizia spirituale, „Rivista di Filosofia Neo-Scolastica” 98 (2006), nr 1 (gennaio-marzo), s. 131-137.

3 M.F. Mellano, Anni decisivi della vita di A. Rosmini (1848-1854), Roma 1988, s. 12. 
nazywany przez znawców „ojcem europejskiego personalizmu”4. Według koncepcji filozofa z Rovereto „osoba jest najwyższą zasadą w jednostce rozumnej”. W swoim Katechizmie ułożonym wedtug porzadku rzeczy pierwsze pytanie, jakie stawia Rosmini czytelnikowi, brzmi: „Kim jesteś?”, a następne „Kim jest człowiek?”.

Przybliżenie czytelnikowi filozoficznego obrazu człowieka i koncepcji osoby w pismach włoskiego filozofa jest pierwotnym motywem napisania niniejszego przedłożenia. Poszukuje się w nim odpowiedzi na pytania: Na ile filozoficzna wizja człowieka wypracowana w wieku XIX zachowała swoją ponadczasowość i uniwersalność? Czy może być zastosowana w krytycznym i twórczym spojrzeniu na człowieka XXI w.? Na ile przemyślenia dziewiętnastowiecznego filozofa mogą być pomocne w diagnozie i poszukiwaniu dróg wyjścia z ewidentnego dziś kryzysu antropologii i aksjologii? Drugą racją powstania tego artykułu jest relatywnie skąpa literatura polskojęzyczna poświęcona włoskiemu kapłanowi, traktująca zarówno o jego osobie, jak i o jego myśli ${ }^{7}$.

\section{Koncepcja bytu A. Rosminiego}

Przed zarysowaniem i omówieniem zrębów antropologii Antonia Rosminiego ${ }^{8}$ zasadne wydaje się zaprezentowanie jego poglądów na temat ontologii, czyli nauki o bycie w ogólności, gdyż nowatorska koncepcja trójpodziału bytu stworzona przez włoskiego filozofa ma daleko idące konsekwencje w definiowaniu i opisie pojęcia osoby. Według Roveretańczyka w skład bytu wchodzą trzy akty, inaczej trzy komponenty: byt idealny (eesere ideale), byt realny (essere reale) oraz byt moralny (essere morale $)^{9}$.

Byt idealny to taka forma bytu, w której byt jawi się jako przedmiot. Dzięki niej człowiek może poznać dwie pozostałe formy bytu. Byt w postaci idealnej jest formą obiektywną bytu i dzięki temu może odsłonić swoje istnienie przed ludzkim rozumem, który to właśnie jest przedmiotem bytu idealnego. Byt idealny sam w so-

4 Zob. R. Skrzypczak, Filozofia i teologia osoby bt. Antonio Rosminiego - ojca personalizmu chrześcijańskiego, Kraków 2013.

5 A. Rosmini, Antropologia in servizio della scienza morale, Roma 1981, s. 460.

6 A. Rosmini, Catechismo disposto secondo l'ordine delle idee, Roma 1898, s. 5.

7 Bibliografia polska na temat życia lub myśli A. Rosminiego obejmuje niewiele ponad 50 pozycji. Zob. P. Borkowski, Bibliografia polska Antonia Rosminiego, „Człowiek w Kulturze" 18 (2006), s. 197-202.

8 W dalszej części artykułu będą używane, celem unikania powtórzeń, inne określenia osoby Antonia Rosminiego, takie jak: Roveretańczyk, filozof ze Stresy (to miejsce powstania większości dzieł Rosminiego) czy też Błogosławiony ze Stresy (w nawiązaniu do faktu jego rehabilitacji i beatyfikacji przez Stolicę Świętą). Takie określenia są bezpośrednimi tłumaczeniami z włoskojęzycznych biografii Rosminiego (Roveretano, filosofo di Stresa, Beato di Stresa).

9 A. Rosmini, Introduzione alla filosofia, Roma 1979, s. 326. 
bie jest fundamentem wszelkiego poznania, ponieważ pierwszym jego elementem jest poznanie istnienia rzeczy, która ma być poznawana, faktu, że owa rzecz w ogóle istnieje. Dopiero na dalszym etapie podejmuje się refleksję co do istoty i przymiotów poznawanego bytu. Właśnie istnienie jest elementem wspólnym wszystkich rzeczy poznawanych i koniecznym do ich kognicji. Gdyby hipotetycznie odebrać rzeczom ich istnienie, nie mogłyby zostać poznane. Według Rosminiego byt idealny jest podstawową zasadą wewnętrznego porządku istnienia. Mówiąc w sposób obrazowy, gdyby człowiek miał wgląd w swoje własne istnienie, pierwszym elementem, który by dostrzegł, byłby właśnie byt idealny, czyli najczystsza forma istnienia. Jest ono niezbędnym światłem, bez którego niemożliwe byłyby dalsze etapy poznania. Pozbawienie osoby ludzkiej tego elementu (bytu w jego formie idealnej) skutkowałoby jednocześnie pozbawieniem człowieka inteligencji, gdyż nie mógłby on rozpoznawać rzeczy jako takich ani ich podmiotowości ${ }^{10}$.

Czysta substancja bytu ukazuje człowiekowi podstawową rację wewnętrznego porządku samego bytu. Sam człowiek za pomocą tej racji nie poznaje samego realnego bytu, jest zdolny poznać formę, a nie istotę bytu. Byt idealny jest również główną racją istnienia przypadłości w bycie. Byt idealny można rozumieć jako początek każdej rzeczy w sensie logicznym. Jest on jakby światłem, które oświetla ludzkiemu intelektowi drogę, jaką przemierza w procesie poznania ${ }^{11}$.

Jakie są główne cechy bytu idealnego? Jakie cechy pozwalają na odróżnienie tego bytu od innych bytów? Są to przede wszystkim: jego nieskończoność, niezmienność, wieczność i konieczność istnienia. Ważnym zastrzeżeniem ze strony filozofa $\mathrm{z}$ Rovereto jest uwaga, że bytu idealnego nie można utożsamić z osobą. Aby uniknąć oskarżenia o panteizm, Rosmini twierdzi, że jest on przynależny Bogu, ale nie jest samym Bogiem, a tylko przejawem nieskończoności (Boga) tkwiącym w skończoności (człowieku) ${ }^{12}$.

Drugi rodzaj bytu wyodrębniony w myśli Rosminiego to tzw. byt realny ${ }^{13}$. Aby dobrze zrozumieć jego koncepcję, należy rozpocząć od pojęcia kontyngencji bytu, czyli inaczej jego przygodności. W filozofii klasycznej polega ona na niekonieczności istnienia, kruchości, utracalności istnienia przez osoby i rzeczy ${ }^{14}$. Wszystkie byty, które otaczają człowieka, są kontyngente, czyli są realne, ponieważ istnieją, ale do ich istoty należy również cecha niekonieczności istnienia. Mogłyby nie istnieć. Najważniejszy jednak dla włoskiego filozofa jest fakt ich realnego istnienia. Stąd Roveretańczyk wyprowadza wniosek, że byty przygodne, aby być poznane, muszą łączyć się, jednoczyć z bytem obiektywnym ${ }^{15}$.

10 S.F. Tadini, Il problema di Dio nella metafisica rosminiana, Milano 2015, s. 206.

11 S.F. Tadini, Il problema ..., dz. cyt., s. 206.

12 A. Rosmini, Teosofia, t. 2, Roma 1999, s. 271.

13 A. Rosmini, Introduzione alla filosofia, dz. cyt., s. 326.

14 A. Maryniarczyk, Przygodność bytów, w: Powszechna encyklopedia filozofii, t. 8, Lublin 2007, s. 545.

15 S.F. Tadini, Il problema ..., dz. cyt., s. 207. 
Akt zjednoczenia się obydwu wyżej wspomnianych rodzajów bytu należy do zadań ludzkiego poznania intelektualnego. Dzięki niemu człowiek może stwierdzić istnienie obiektu poznawanego swoimi zmysłami. Byt skończony posiada zdolność wejścia w człowieka poprzez poznanie zmysłowe. Zmysły zaś są rozświetlane poprzez byt idealny ${ }^{16}$. Mocą tego aktu poznawczego podmiot poznający - człowiek w pewien sposób przyswaja sobie byt realny rozpoznany w jego istocie. Proces ten odbywa się według Rosminiego poza czasem i przestrzenią.

Istnienie bytu $\mathrm{w}$ jego formie realnej jest według włoskiego filozofa warunkiem koniecznym poznania bytu idealnego. Tak jak konieczny jest przedmiot poznania (byt idealny), tak samo konieczny jest umysł, czyli inteligencja podmiotu, który dokonuje aktu poznania ${ }^{17}$.

Trzecią formą bytu jest jego postać moralna. Rosmini rozumie ją i przedstawia w kategoriach dobra na płaszczyźnie aksjologicznej. Widzi w niej pełną syntezę i wypełnienie bytów w ich doskonałości. Określa ją jako zjednoczenie w miłości bytu realnego i bytu idealnego ${ }^{18}$. „Nie należy zatem mylić porządku fizycznego istnienia ani porządku racjonalnego idei z porządkiem moralnym. Ten ostatni łączy dwa pierwsze, udoskonala je, dopełnia, nadając im formę pełnego dobra" ${ }^{19}$. Dla Roveretańczyka prawda i dobro nie są tożsame. Sam akt poznania jest neutralny moralnie. Moralność zaczyna obowiązywać dopiero wtedy, gdy to, co poznawane, jest pożądane jako dobro i miłowane jako byt. Człowiek dopiero w pewien sposób wyrzekając się siebie, zapominając o sobie samym, odnajduje się w poznawanym przedmiocie i dopiero wtedy staje się moralny. To odnalezienie siebie w poznawanym przedmiocie Rosmini określa terminem inoggetivizzazione, który można oddać jako „wejście w poznawany przedmiot” albo „wprzedmiotowienie”. W myśl tej teorii podmiot inteligentny przenosi się i osadza się w bycie takim, jakim on jest, ciąży ku niemu i zespala się z nim całą swoją wolą i całym sobą ${ }^{20}$.

\section{Definicja i cechy osoby}

Według filozofa $\mathrm{z}$ Rovereto jedynie człowiek jest bytem zdolnym do osiągnięcia trzech kategorycznych form bytu. Podmiot poznający, przedmiot poznania, a także poznający wspólnie tworzą formę idealną, realną i moralną bytu ${ }^{21}$. Dokonując syntezy ontologicznej wizji osoby ludzkiej Rosminiego, można wyróżnić kilka właściwości, które pozwalają odróżnić osobę od innych bytów. Po pierwsze, osoba musi być substancją jako jedna (unica) i niewidzialna (invisibile). Po wtóre, musi być jednostką (individuo) stanowiącą fragment rzeczywistości realnej, a nie tylko świata

\footnotetext{
16 A. Rosmini, Teosofia, t. 2, dz. cyt., s. 27.

17 A. Rosmini, Teosofia, t. 2, dz. cyt., s. 819.

18 A. Rosmini, Introduzione alla filosofia, dz. cyt., s. 282.

19 A. Rosmini, Il principio della morale, Bari 1914, s. 32-33.

20 A. Rosmini, Teosofia, t. 2, dz. cyt., s. 342.

21 A. Rosmini, Psicologia, libri dieci, Roma 1988, s. 112.
} 
idei. Osoba, aby nią być, musi być wyposażona w inteligencję (intelligente). Kolejną cechą ontologiczną osoby jest bycie zasadą aktywną (principio attivo). Należy doprecyzować, że aktywność jest tu rozumiana w znaczeniu możliwie najszerszym, co powoduje, że osoba jest taką zasadą, z której bierze początek nie tylko wszelka aktywność, lecz również pasywność jednostki. Według Rosminiego w jednostce nie ma niczego, co by osobę przewyższało, i nie ma też niczego, od czego mogłaby ona otrzymywać istnienie ${ }^{22}$. Ostatnią, szóstą właściwością osoby jest jej nieprzekazywalność (incomunicabilità), inaczej mówiąc, jej niepowtarzalność. Każdy jest samym sobą, różnym od innych, istotowo jednym i unikalnym. Dzięki tej własności osoba może wchodzić w relacje z innymi osobami, tworząc „my” bez ryzyka utraty własnej tożsamości substancjalnej. Jeśli zatem na świecie istnieje wiele osób, każda $\mathrm{z}$ nich jest nieprzekazywalnym podmiotem ${ }^{23}$, uważa Rosmini.

W antropologicznej koncepcji Rosminiego osoby nie utożsamia się ze świadomością. Chronologicznie osoba pojawia się przed świadomością, która będąc rozumieniem tego, kim się jest, pojawia się na dalszym etapie istnienia. Osoba nie może być również zredukowana do szczególnych, ale tylko częściowych właściwości psychologicznych, takich jak instynkt życiowy czy seksualny, ani też tylko sfery afektywnej bądź wolitywnejej.

Rosmini w swoich rozważaniach rozróżnia wyraźnie podmiot (soggetto) i osobę (persona). Te dwa pojęcia w jego myśli nie są ze sobą tożsame i nie mogą być stosowane zamiennie. Pojęcie podmiotu jest pojęciem szerszym i odnoszącym się do ogółu bytów, jest zasadą aktywną obecną w każdym bycie odczuwającym, bez względu na to, czy dany byt jest wyposażony w inteligencję, czy też nie. Natomiast pojęcie osoby jest nierozerwalnie związane z przymiotnikiem ,inteligentny”, co powoduje zawężenie definicji do określonego zbioru bytów. Osoba jest specyficznym rodzajem podmiotu, który nosi w sobie byt jako przedmiot. Cecha ta skutkuje nabyciem godności i statusu celu w odniesieniu do innych istniejących bytów. Ustalenia te doprowadziły filozofa z Rovereto do określenia człowieka jako „podmiotu zwierzęcego obdarzonego intuicją bytu idealnego niezdeterminowanego i percepcją własnego podstawowego odczucia cielesnego oraz działającego według zwierzęcości i inteligencji”'25.

Warto zwrócić uwagę na dwa elementy tego określenia. Najpierw wprowadza ono pojęcie bytu idealnego i podstawowego odczucia cielesnego. Dzięki wrodzonej idei bytu, którą człowiek posiada, poznanie ludzkie zyskuje walor transcendentalności. Dzięki temu człowiek w poznaniu i rozumowaniu może się wznieść aż do stwierdzenia konieczności istnienia Boga, dostrzeżenia realnej hierarchii bytowej itd., czego żadne zwierzę uczynić nie może. Kolejny ważny element tej definicji to podkreślenie faktu, że poprzez podstawowe odczucie cielesne człowiek przyporząd-

22 A. Rosmini, Antropologia in servizio..., dz. cyt., s. 461-462.

23 A. Rosmini, Teosofia, t. 2, dz. cyt., s. 436.

24 A. Rosmini, Antropologia in servizio..., dz. cyt., s. 465.

25 A. Rosmini, Antropologia in servizio..., dz. cyt., s. 40. 
kowuje całą swą cielesność podmiotowi - osobie - w sposób świadomy i wolny ${ }^{26}$. Jednocześnie zwierzęcość człowieka nie stoi w opozycji do władz intelektualnych, lecz stanowi nieodłączny element realizowania się człowieka jako podmiotu ${ }^{27}$. Według Rosminiego ludzki podmiot osobowy składa się niejako z dwóch różnych, lecz równych co do znaczenia części: biernej i aktywnej. Część aktywna jest ukonstytuowana przez wolę oraz inteligencję, na część pasywną składa się zwierzęcość oraz intelekt rozumiany jako wrodzona umiejętność przeczuwania idei bytu ${ }^{28}$. Owe atrybuty osoby pozwalają na jej odróżnienie $\mathrm{z}$ jednej strony od aniołów ${ }^{29}$, $\mathrm{z}$ drugiej zaś od świata zwierząt. Osoba ludzka jest więc idealnym połączeniem pierwiastka zwierzęcego i duchowego, którego domeną są akty intelektu i woli ${ }^{30}$.

W języku włoskim pierwiastek zwierzęcy - lub mówiąc inaczej: cielesny - osoby określa się terminem animalità. Termin ten posiada dwa rdzenie znaczeniowe: animale - «zwierzę», ale również anima - «dusza, duch». Dlatego też w ujęciu Rosminiego animalità nie oznacza samej cielesności ciała, które może wywoływać i odbierać doznania zmysłowe, ale także duchową zasadę transcendentną, która jest zawarta w samej istocie tychże doznań. Zasada czująca, zmysłowa w człowieku, czyli dusza, jest zdolna tylko do biernego odbierania doznań, lecz sama ich nie może wzbudzać, natomiast część cielesna człowieka jest zdolna te doznania wywoływać, ale nie odczuwać. Trzeba tu jedna doprecyzować, że według Roveretańczyka czucie nie oznacza tutaj bycia świadomym samego siebie, gdyż jest to możliwe tylko dzięki działaniu wyższych władz duchowych, innych niż właściwe poznaniu materialne$\mathrm{mu}^{31}$.

W opozycji do twierdzeń naturalistów, którzy za przejawy życia cielesnego uznają tylko fenomeny podpadające pod poznanie zmysłowe i zewnętrzne, filozof z Rovereto twierdzi, że życie zawsze jest związane z odczuwaniem, a jego siedliskiem jest dusza, gdzie znajdują się tylko odczucia w sensie filozoficznym. Dlatego kiedy mówi o życiu fizycznym, zawsze odnosi to do duszy poznającej, w której można rozpoznać tylko „zmysł życia” (sentimento della vita), czyli „podstawowe doznanie cielesne" ${ }^{\prime 2}$.

Tym, co wyróżnia człowieka spośród innych stworzeń, jest istniejące w jego duchowym wnętrzu wrodzone światło rozumu, które pozwala widzieć rzeczy w peł-

${ }^{26}$ K. Wroczyński, Człowiek, osoba i prawo w świetle definicji Antonia Rosminiego, „Człowiek w Kulturze" 18 (2006), s. 102-103.

27 R. Zama, La persona e la libertà in Rosmini, Stresa 2006, s. 100.

28 A. Rosmini, Antropologia in servizio..., dz. cyt., s. 40-41.

${ }^{29}$ „Nawet anioł, gdyby mechanicznie został wyposażony w ciało bez świadomości siebie, nie byłby jeszcze człowiekiem” („E veramente un Angelo, il quale si fornisse di un corpo come di una macchina senza informarlo di sé, non sarebbe uomo"). A. Rosmini, Antropologia in servizio..., dz. cyt., s. 33.

30 A. Rosmini, Antropologia in servizio..., dz. cyt., s. 41.

31 R. Zama, La persona..., dz. cyt., s. 101

32 A. Rosmini, Antropologia in servizio..., dz. cyt., s. 60. 
nej prawdzie, a więc ujmować wszystkie rzeczy intelektualnie poprzez ich idee. Kontakt zwierząt ze światem zewnętrznym i wzajemnie pomiędzy nimi rozgrywa się na poziomie zmysłów i nie ma charakteru ściśle poznawczego. To ludzki kontakt z rzeczywistością ma charakter ze wszech miar poznawczy, ponieważ dzięki intelektowi człowiek może poznawać istotę rzeczy, rzeczy same w sobie, osadzone w ludzkim intelekcie w formie bytu idealnego. To właśnie fakt samopoznania siebie jako podmiotu rozumnego w akcie intelektualnego poznania czegokolwiek należy wytłumaczyć doskonalszym czy wręcz najdoskonalszym sposobem bytowania osoby $^{33}$. Według koncepcji filozofa $\mathrm{z}$ Rovereto „osoba jest najwyższą zasadą w jednostce rozumnej”34. Rozumność jest cechą konstytutywną, związaną nierozerwalnie z podmiotowością osoby. Cechy tej nie można nabyć w drodze rozwoju. Rosmini określa ją jako ,światło rozumu” (lume della ragione) i przyznaje tej władzy wiodącą rolę w procesie samopoznania, niezbędnym osobie do osiągnięcia statusu istoty autonomicznej, posiadającej w sobie samej zasadę swego działania. Dzięki tej cesze człowiek transcenduje swoją naturę i odkrywa siebie jako byt posiadający światło rozumu $^{35}$. Ponieważ akty poznawcze człowieka są jego aktami na wskroś osobowymi, za ich sprawą człowiek przekracza naturę i budzi się bogatszy o swoje poznanie, odkrywając tym samym siebie jako istotę wyposażoną w światło rozumu. To światło stanowi w koncepcji osoby Rosminiego centralny i niezbywalny element konstytuujący osobę, który czyni z osoby ludzkiej istotę autonomiczną, posiadającą w sobie samej zasadę swego działania.

Na szczególną uwagę zasługuje inna jeszcze definicja osoby według Rosminiego: jako „relacji subsystentnej” (relazione sussistente) ${ }^{36}$. Subsystencja to specyficzne działanie: wszczepianie się albo przyjmowanie do siebie, a także sytuacja, która jest skutkiem tego działania: usadowienie się w innym bycie albo usadowienie innych bytów w sobie. W odniesieniu do drugiej sytuacji używany jest również określenie „subsystowanie”. W sensie potencjalności, czy też inaczej: możności, subsystentność to zdolność substancji do tego, by stanowić fundament innej substancji, a także możliwość usadowienia się w innej substancji. Natomiast w sensie aktualizacji przymiot subsystentności realizuje się poprzez realne bycie fundamentem dla innej substancji albo poprzez realne usadowienie się w innej substancji. Analogicznie do tego, jak substancjalność jest cechą bytu, który jest substancją, cechą bytu subsystującego jest subsystentnośćc ${ }^{37}$.

Fundamentem omawianej definicji Rosminiego jest dziedzictwo myśli filozoficznej św. Augustyna i św. Tomaszu z Akwinu, którzy przyczynili się w znaczą-

33 A. Wierzbicki, Osoba jest prawem. Komentarz do Antonio Rosminiego personalistycznej koncepcji prawa, „Ethos” 12 (1999), nr 1-2, s. 97.

${ }_{34}$ A. Rosmini, Antropologia in servizio..., dz. cyt., s. 460.

${ }_{35}$ A. Wierzbicki, Osoba jest prawem ..., art. cyt., s. 98.

36 A. Rosmini, Teosofia, t. 3, Roma 1999, s. 195.

${ }^{37}$ P. Liszka, Znaczenie terminu „subsystentność” w teologii chrześcijańskiej, „Teologia w Polsce" 12 (2018), z. 1, s. 41-54. 
cy sposób do przywrócenia zagadnieniu relacji należnego miejsca w rozważaniach antropologicznych. Ujmując ich myśl syntetycznie, można stwierdzić, że nie jest możliwe analizowanie istoty jakiegokolwiek samoistnego bytu bez odniesienia go w sposób konieczny do innego podobnego bytu ${ }^{38}$.

„Kiedy umysł zestawia dwa byty istniejące, dostrzega jeden z nich, ale tak, że nie da się go zobaczyć pojedynczo, oddzielnie, bez uwzględnienia drugiego, taki rodzaj istnienia nazywa się relacją, czyli istnieniem, którego nie da się pomyśleć w oderwaniu jednego od drugiego, gdyż pomiędzy nimi przebiega relacja. Nie odnosi się to tylko do bytów abstrakcyjnych, ale także do rzeczywistości realnych i bytowo samodzielnych (subsystentnych)"39. Z powyższej definicji filozof z Rovereto wyprowadza daleko idący pod względem konsekwencji antropologicznych wniosek, że każdy element rzeczywistości, każdy byt, który nie jest osobą, nie może istnieć bez odniesienia do osoby ${ }^{40}$. Ma to poważne skutki praktyczne. Rzeczy dla człowieka mają status tylko i wyłącznie środka, celem natomiast bytowania jest osoba. W myśl takiego rozumowania na płaszczyźnie ontologicznej byty nieosobowe nie istnieją same w sobie. W systemie metafizycznym Rosminiego osoba jest ontologicznym centrum świata. Sam Stwórca podniósł człowieka do najwyższej godności i pomimo swojej wszechmocy i wszechpotęgi włada ludźmi z najwyższym szacunkiem ${ }^{41}$. Osoba jako relacja subsystentna jest otwarta i nosi w sobie dezyderat kontaktu z całością bytu, i dąży do niego z poszanowaniem właściwej hierarchii, czyli szanując rzeczy jako środki, inne osoby jako cele względne, Boga zaś jako cel ostateczny swojej egzystencji. Człowiek w głębi swojej istoty jest nieustannym poszukiwaniem innych, potrzebą drugiego, wspólnotą z innymi ${ }^{42}$. „Wszystko, co istnieje w świecie, przypomina łańcuch, którego ogniwa są zawieszone na pierwszym ogniwie, jakim jest osoba. Osoby istniejące na świecie są celem wszystkich innych rzeczy nieosobowych, z którymi są ściśle związane przez połączenia fizyczne, dynamiczne, intelektualne, moralne i o których można powiedzieć, że w każdym sensie istnieją dla osoby"43.

Będąc kapłanem i teologiem, Rosmini określa osobę jako „nowego człowieka”. Według niego istota ludzka pielęgnująca w sobie tylko pierwiastek zwierzęcy potrzebuje przeobrażenia w „człowieka nowego”, którego cechuje „odczuwanie podmioto-

38 Myśl tę podjęli i rozwinęli kolejni włoscy filozofowie, a szczególnie M.F. Sciacca (19081975). Zob. M.F. Sciacca, Il problema dell'essenza della religione nella storiografia filosofica italiana, w: Opere complete, t. 38, Milano 1973, s. 372-374. Zob. A. Nowicki, Wspótczesna filozofia włoska, Warszawa 1977.

39 A. Rosmini, Teosofia, t. 2, dz. cyt., s. 352.

40 A. Rosmini, Logica, t. 2, Milano 1942-1943, s. 141.

41 A. Rosmini, Logica, t. 2, dz. cyt., s. 152.

42 Temat otwartości na drugiego człowieka w aspekcie filozoficznym Rosmini pogłębia i rozwija w swojej Teosofii.

43 A. Rosmini, Chiamata di tutti gli uomini alla santità in Cristo, Stresa 2007, s. 29. 
we" - uczestnictwo w życiu Chrystusa. W tym zawiera się pełnia życia ${ }^{44}$. Człowiek nowy, czyli osoba stworzona na Boży obraz i podobieństwo, jest obdarzony Bożą miłością. Dzięki temu następuje wymiana: człowiek obdarowany miłością odpowiada Stwórcy, w ten sam sposób wyśpiewując Mu swoim życiem pieśń miłosną. W ten sposób rodzi się niebiańska harmonia pomiędzy Bogiem a człowiekiem. „Miłość jak słodki, a jednocześnie mocny dźwięk harfy przenika serce człowiecze i bierze go w posiadanie, przenosząc i składając w duszy Chrystusa, gdzie zły duch nie ma dostępu"45.

Bóg według Roveretańczyka odnowił świat pięknem swojej miłości, a człowiek, uczestnicząc w rozkoszy tej miłości, korzysta równocześnie z piękna, jakie się w niej zawiera. Poprzez to cudowne lekarstwo, jakim jest piękno Bożej miłości, Chrystus uzdrowił świat porażony egoizmem ${ }^{46}$. Tak więc nowy człowiek, czyli człowiek-osoba nie tylko został obdarzony przez Stwórcę wolną wolą, wolnością i inteligencją, ale pozostaje z Nim w relacji miłości. Dlatego też zasadą relacji pomiędzy poszczególnymi pojedynczymi osobami powinna być miłość. Żadna władza ludzka nie może dążyć do zniszczenia ani choćby zepsucia miłości człowieka wobec Boga czy też innych ludzi ${ }^{47}$. To przekonanie Rosmini wywodzi z faktu, że każdy człowiek ,wie, że ma Przyjaciela, który go nigdy w miłości nie zawiedzie, i wie również, że nieskończona miłość Chrystusa nie umniejsza się na skutek niekończących się i ogromnych aktów niewierności człowieka, ale wszystkie one nikną w bezmiarze Jego miłosierdzia. Im większa niewierność, tym mocniej świeci blask miłosierdzia" $"$.

Tak więc ludzie są osobami, a nie wytworami ludzkiego geniuszu. Są osobami stworzonymi przez Boga, posiadającymi ciało i duszę, których ostatecznym i najwyższym celem jest ich Stwórca. Nikt nie może niszczyć ani sprzeciwiać się temu naturalnemu dążeniu człowieka do jedności z Bogiem ${ }^{49}$.

$\mathrm{Z}$ faktu ontologicznego odseparowania człowieka od reszty stworzenia wynikają daleko idące konsekwencje. Po pierwsze, osoba jest pierwszym i najważniejszym bytem w porządku naturalnym i nie może w swojej istocie być podporządkowana, być własnością jakiejkolwiek innej osoby ani instytucji. Po drugie zaś, człowiek jest zobowiązany do utrwalania i pogłębiania wewnętrznej harmonii pomiędzy elementem duchowym i cielesnym, pomiędzy instynktem a siłą inteligencji i wolnej woli ${ }^{50}$.

44 A. Rosmini, L'introduzione del Vangelo secondo Giovanni commentata, Roma 2009, s. 243.

45 A. Rosmini, Storia dell'amore ricavata dalle divine Scritture, Padova 1975, s. 128.

46 P. Addante, Antonio Rosmini. La persona umana, malessere, diagnosi e terapia dell'amore, Reggio Calabria 2008, s. 38.

47 P. Addante, Antonio Rosmini..., dz. cyt., s. 39.

48 A. Rosmini, Storia dell'amore..., dz. cyt., s. 33.

49 P. Addante, Antonio Rosmini..., dz. cyt., s. 39.

50 M.F. Sciacca, Il composto umano nel pensiero di Antonio Rosmini, „Atti del IV Convegno Nazionale di Medicina Omeopatica”, Roma, 15-18 Sett. 1969, w: M.F. Sciacca, Interpretazioni rosminiane, Milano 1971, s. 20. 
Największymi wrogami człowieka zdefiniowanymi przez Rosminiego są siły zła inspirowane przez diabła, rozumiane jako różne przejawy ucisku czy przemocy obecne w świecie. Wrogiem dla siebie może stać się również sam człowiek, który niszcząc wspomniany wyżej ład wewnętrzny, nie jest zdolny działać uczciwie na płaszczyźnie etycznej ani religijnej. Nie będąc w stanie prawidłowo rozpoznawać prawdy, człowiek tworzy nieporządek w sobie samym, we wspólnotach społecznych i politycznych, a także pomiędzy organizacjami na poziomie międzynarodowym ${ }^{51}$. Dlatego konieczne jest umacnianie nowego człowieka poprzez pracę nad sobą i walkę duchową ${ }^{52}$.

Ponieważ każdy człowiek według teologii katolickiej jest naznaczony skazą grzechu pierworodnego, która to rana powoduje w człowieku skłonność do czynienia zła, wpływając na wolną wolę, do skutecznego podjęcia duchowej walki ze skutkami grzechu Adama i Ewy konieczna jest łaska. Przez Rosminiego jest ona definiowana jako „boskie działanie, które poprzez realną i głęboką więź łączy ducha ludzkiego z boskością"53. Nie jest to aktywność jednorazowa lub okazjonalna. Bóg poprzez łaskę jednoczy się z osobą w sposób trwały, tak że w człowieku pojawia się element boski wcześniej w duszy nieobecny ${ }^{54}$. „Wraz z łaską Chrztu świętego człowiek zostaje wyposażony w nową inteligencję, dzięki której rozum pojmuje samego Boga. I w ten sposób rodzi się nowy umysł, będący w stanie dostrzegać w sposób konkretny rzeczywistość nadprzyrodzoną. Tworzy się nowe podstawowe odczuwanie w znaczeniu ontologicznym, nie psychologicznym - odczucie wiary. To odczucie formuje nowego człowieka, podobnie jak podstawowe zwierzęco-racjonalne odczucie kształtuje człowieka naturalnego. Obydwa rodzaje odczucia są substancjalne, to znaczy tworzą ja" ${ }^{55}$.

W wyniku działania łaski powstaje zdaniem Rosminiego osoba nowa, czyli nowa zasada aktywna, nadprzyrodzona, wznioślejsza i wyższa, jednak nieustannie zbudowana na tym samym podmiocie. Niezmienna pozostaje substancja inteligentna, w przeciwnym bowiem razie człowiek nie miałby własnej osobowości po złączeniu się ze Słowem. Przedmiot (łaska) nie może być utożsamiany z podmiotem (osobą), wręcz przeciwnie: pozostaje od niego zupełnie odrębny ${ }^{56}$. Pomimo ścisłej łączności z Bogiem poprzez działanie łaski osoba zachowuje w pełni swoją autonomię. Współpraca $z$ działaniem łaski, otwarcie się na nią jest warunkiem koniecznym do zrealizowania postulatu pełnego otwarcia się na Absolut, co z kolei zgodnie z myślą Rosminiego nie jest możliwe do osiągnięcia bez pośrednictwa Chrystusa. Człowiek z poziomu dominacji w nim pierwiastka zwierzęcego musi przejść transformację w nowego człowieka, co w praktyce oznacza rozpoznanie siebie jako osoby

51 P. Addante, Antonio Rosmini..., dz. cyt., s. 40.

52 A. Rosmini, L'introduzione del Vangelo..., dz. cyt., s. 190.

53 A. Rosmini, Antropologia sopranaturale, t. 1, Roma 1983, s. 75.

54 A. Rosmini, Antropologia sopranaturale, t. 1, dz. cyt., s. 89.

55 R. Skrzypczak, Filozofia i teologia ..., dz. cyt., s. 164.

56 Por. A. Rosmini, Antropologia sopranaturale, t. 1, dz. cyt., s. 296-305. 
i działanie w sposób osobowy. To z kolei skutkuje niezbywalnym prawem do bycia traktowanym jako osoba. Jest to droga do realizacji postulatu salvata la persona, è salvato l'uomo, perita la persona è perito l'uomo, czyli „gdy ocalimy osobę, ocalimy człowieka, jeśli osoba zginie, zginie również człowiek"57.

Filozof z Rovereto podaje również inną, jeszcze bardziej skondensowaną definicję człowieka jako „podmiotu zwierzęcego obdarzonego intelektem i wolą” (un soggetto animale, intellettivo e volitivo ${ }^{58}$. To określenie jest dobrym punktem wyjścia do podjęcia rozważań na temat kolejnego ważnego aspektu antropologicznego, jakim jest podejście Rosminiego do pierwiastka cielesnego.

Od zarania chrześcijaństwa dyskusja na temat relacji sfery fizycznej do sfery duchowej przetaczała się przez historię, począwszy od sporu manichejskiego aż po teologię ciała Jana Pawła $\mathrm{II}^{59}$. Temat cielesności przewija się w pismach Rosminiego od początku do końca jego pisarskiej aktywności. Za punkty graniczne można tu uznać dwie prace: Esej o nadziei przeciwko niektórym błędnym twierdzeniom Ugo Foscolo (Saggio sulla speranza contro alcuni errori di Ugo Foscolo) ${ }^{60}$ z 1822 r. i wydaną w 1858 r. Psychologię (Psicologia).

Główne źródło wiedzy na temat podejścia Rosminiego do cielesności można znaleźć w jego wspomnianym i cytowanym już dziele Psychologia. Dla współczesnego czytelnika mylący może być już sam tytuł książki. Filozof z Rovereto pojmuje psychologię jako całościową wiedzę o człowieku, gdyż - jak twierdzi - człowiek jest jednością, a zatem i nauka zajmująca się nim powinna być jedna. Ale niestety w ciągu wieków poprzez abstrakcyjne rozważania człowiek został rozczłonkowany, co w konsekwencji doprowadziło do powstania wielu dziedzin nauki zajmujących się istotą ludzką ${ }^{61}$. Jak pisze Rosmini: „specjaliści od fizjologii i psychologii brutalnie rozparcelowali człowieka pomiędzy siebie w mylnym przekonaniu, że każda z tych grup posiada go w całości. Tak więc pierwsi myśleli, że człowiek jest zły i brzydki, drudzy natomiast, że jest aniołem. Chcemy ponownie złożyć w całość człowieka tak nikczemnie rozpołowionego" ${ }^{\prime 2}$. W myśl tej integralnej wizji człowieka włoski myśliciel przypomina, że człowieka należy rozumieć w istocie jako podmiot wyposażony w duszę, w którym koegzystują odczucia cielesne i intelektualne.

Dusza do swojego funkcjonowania, wypełnienia swoich zadań, w tym także myślenia potrzebuje powłoki cielesnej, zawiązując z nią doskonałą relację symbiozy. Pierwiastek fizyczny potrzebuje zasady odczuwającej, której będzie wyznaczał

57 A. Rosmini, L'introduzione del Vangelo..., dz. cyt., s. 243.

58 A. Rosmini, Antropologia in servizio..., dz. cyt., s. 37. Zob. U. Muratore, Conoscere Rosmini. Vita, pensiero, spiritualità, Stresa 1999, s. 83-84.

59 K. Wojtyła, ,Osoba i czyn” oraz inne studia antropologiczne, Lublin 2000; K. Wojtyła, Miłość i odpowiedzialność, Lublin 2001.

60 Zob. A. Rosmini, Saggio sulla speranza contro alcuni errori di Ugo Foscolo, Charleston 2012.

61 A. Rosmini, Psicologia ..., dz. cyt., s. 34.

62 A. Rosmini, Psicologia ..., dz. cyt., s. 34. 
kres, podobnie dusza potrzebuje materii, dla której będzie zasadą, gdyż bez niej materia gubi sens swojego istnienia. Dusza poznaje i poddaje refleksji poznawczej rzeczywistość poprzez cielesność. Jednocześnie dusza niejako nadaje sens ciału, bez którego jednocześnie nie mogłaby spełniać swoich funkcji. W tej zależności źródłem i początkiem jest byt autonomiczny, różny od jednostki, czyli Bóg. Jedynie dzięki Jego woli byt może istnieć i być pomyślany, a co za tym idzie - poznawać i być poznawany poprzez akty poznania zmysłowego oraz intelektualnego. Rezultatem tego poznania jest odkrycie człowieka jako bytu złożonego z duszy i ciała, zanurzonego w rzeczywistości, w której żyje, porusza się, przeżywając radości i cierpienia ${ }^{63}$.

Mówiąc o cielesności, Rosmini dokonuje ważnego rozróżnienia na pojęcie ciała i pojęcie materii. Ciało jest materią podporządkowaną „odczuciu podstawowemu” (il sentimento fondamentale), natomiast jeśli wymyka się ono oddziaływaniu tego odczucia, jest tylko materią. Dzięki temu odczuciu podmiot wchodzi w kontakt z samym sobą. Odczucie to jest odczuciem pierwotnym, uprzedzającym jakiekolwiek inne. Ciało doznaje rozdarcia między dwoma dążeniami: z jednej strony do zatrzymania swego istnienia za wszelką cenę, zakotwiczając się w immanencji, z drugiej zaś jest w nim dążenie do uwolnienia się od tego pragnienia ${ }^{64}$.

W owej dynamice istotne znaczenie ma element duchowy w człowieku. Kolejny raz filozof z Rovereto ukazuje komplementarność osoby ludzkiej. Jeśli usunąć $\mathrm{z}$ uczestniczenia $\mathrm{w}$ tym procesie element duchowy, niechybnie zaprowadzi to do zredukowania ludzkiej natury tylko do elementu cielesnego, a to będzie skutkować filozoficznym materializmem. Stąd według włoskiego myśliciela już prosta droga do budowania społeczeństwa na fundamencie narcystycznego egoizmu, bez wartości duchowych, co uznaje za bardzo niebezpieczne. Z całą stanowczością Rosmini protestuje intelektualnie przeciwko utylitarnemu traktowaniu osoby. Wynika to z jego metafizyki: „Wszystkie byty są rzeczami, niektóre zaś z nich są także osobami, a zatem każda osoba może być rozpatrywana w dwóch aspektach: w aspekcie rzeczy i w aspekcie osoby. $Z$ jednym ważnym zastrzeżeniem: człowiek nie może używać drugiej osoby, tak jakby była przedmiotem lub rzeczą" ${ }^{65}$.

Przyznając niekwestionowaną wartość cielesności, Roveretańczyk przestrzega przed jej przecenianiem, gdyż mogłoby to zaburzyć integralną i komplementarną wizję człowieka, a tym samym doprowadzić do zredukowania go do poziomu przedmiotu. Byłoby to również porzuceniem wizji człowieka przedstawionej przez Chrystusa. Oddalenie się od nauczania Jezusa w dziedzinie antropologii to tak naprawdę oddalenie się od samego człowieka. Zbytnie podkreślenie pierwiastka fizycznego w człowieku mogłoby doprowadzić do negatywnych konsekwencji w postaci posługiwania się ciałem jako środkiem do niepohamowanego kumulowania bogactw i przyjemności ${ }^{66}$.

${ }^{63}$ A. Sgroi, La ,,corporalità” secondo Rosmini, „Bioetica e Cultura” 21 (2012), nr 1, s. 77.

${ }^{64}$ A. Rosmini, Psicologia ..., dz. cyt., 179.

${ }_{65}$ A. Rosmini, Filosofia della politica, Roma 1997, s. 80.

${ }^{66}$ A. Sgroi, La ,corporalità ”..., art. cyt., s. 75-76. 
Powyższe konstatacje wydają się właściwym momentem do omówienia kolejnej definicji człowieka usnutej przez Rosminiego, mocno powiązanej z rolą jednostki w społeczeństwie. Tym, co reguluje wzajemne zależności pomiędzy jednostkami w społeczeństwie, jest prawo. W swoim dziele Filosofia del diritto Rosmini prowadzi wywód, z którego wynika, że osoba nie tylko może posiadać prawo lub prawa, ale $\mathrm{w}$ istocie sama jest prawem. Oto obszerne fragmenty: „Osoba jest podmiotem rozumnym, [...] gdyż posiada najwyższą zasadę działania. Któż nie zdaje sobie sprawy, że definicja ta zbiega się z definicją samego prawa? [...] Najwyższą zasadę działania, czyli podstawę osoby, formuje światło rozumu, dzięki któremu osoba otrzymuje normę sprawiedliwości. Rozum zatem jest w sensie właściwym władzą czynienia rzeczy zgodnych z prawem. Ale ponieważ godność światła rozumu (byt idealny) jest nieskończona, dlatego już nic nie może stać ponad zasadą osobową [...], to znaczy nic nie może stać ponad zasadą, która działa w mistrzu i panu o nieskończonej godności. Sprawia to, że jest ona zasadą ze swej natury najwyższą w taki sposób, że nikt nie ma prawa rozkazywać komuś, kto sam podlega rozkazom nieskończoności. Jeśli zatem osoba jest najwyższą aktywnością ze swej natury, jest rzeczą oczywistą, że inne osoby są związane moralną powinnością niekrzywdzenia jej, choćby nawet myślą, a tym bardziej czynem zmierzającym do jej obrazy i poniżenia, godzącym w jej naturalną wyższość przysługującą jej jako osobie. Krzywda wyrządzona osobie jest sprzeczna z zasadą moralności, którą stwierdziliśmy i wyraziliśmy w postaci normy uznania czynem rzeczy zgodnie $\mathrm{z}$ ich bytem. [...] Osoba zatem posiada w swej naturze wszystkie konstytutywne elementy prawa i dlatego jest ona prawem z racji istoty swego bytu (prawem subsystentnym) oraz istotą prawa" ${ }^{{ }^{67}}$.

Osoba dla filozofa z Rovereto jest konkretną aplikacją prawa, prawem w swojej konkretnej realizacji. Prawo bez osoby jest tylko zbiorem abstrakcyjnych zapisów i reguł. Łamanie norm prawnych polega $\mathrm{w}$ istocie na braku szacunku dla drugiego człowieka w różnych aspektach życia. Przekraczanie przepisów jest obrażaniem czy wręcz znieważaniem drugiej osoby. Respektowanie innych osób jest przejawem praktycznego respektowania norm zawartych w różnego rodzaju kodeksach. Poszanowanie to należy się każdemu człowiekowi od samego początku jego istnienia ${ }^{68}$.

Z faktu, że „osoba jest prawem subsystentnym”, wynikają bardzo praktyczne konsekwencje. Bycie osobą jest nienaruszalne, nie można nikogo pozbawić ani ograniczyć w aktualizacji tej zasady. Aby skutecznie chronić tę godność w człowieku, konieczne są regulacje prawne zawarte w różnego rodzaju kodeksach, regulacjach i nakazach, jak również instytucje, które będą skutecznie egzekwować respektowanie tych praw ${ }^{69}$. Podstawową zasadą odnoszącą się do praw przysługujących osobie ludzkiej jest w myśli Roveretańczyka zasada o doskonałej równości

67 A. Rosmini, Filosofia del diritto, t. 27/A, Roma 2014, s. 25-26.

68 U. Muratore, Idea di persona in Antonio Rosmini, w: Rosmini e Stefanini. Persona, etica, politica. Atti del Convegno, Treviso, 14-15 novembre 1997, Milano 1998, s. 47.

69 G. Campanini, Capograssi e Rosmini, w: Due convegni su Giuseppe Capograssi (RomaSulmona 1986), red. F. Mercadente, Milano 1990, s. 130. 
wszystkich członków społeczeństwa wobec prawa. Jest to conditio sine qua non zaistnienia doskonałej społeczności obywatelskiej, będącej ideałem życia politycznego ${ }^{70}$. Prawa stanowione przez władzę i wszelkie akty rządzenia polegają bardziej na określaniu reguł stosowania przepisów niż ich stanowieniu. Władza jest raczej dystrybucją prawa niż jego posiadaniem ${ }^{71}$. Jeśli jakiś system prawny deprecjonował człowieka-osobę jako swój fundament, Rosmini krytykował go i odrzucał ${ }^{72}$.

Według filozofa z Rovereto przy stanowieniu norm poczesną rolę odgrywają fundamentalne prawa człowieka ${ }^{73}$. Prawa te można podzielić generalnie na dwie grupy: prawa wolnościowe i prawa dotyczące własności. Prawa własnościowe są gwarantowane i chronione przez rządzących wybieranych przez właścicieli. Ochrona praw odnoszących się do wolności jest kompetencją sędziów wybieranych przez ogół w wyborach powszechnych ${ }^{74}$. Z pism Roveretańczyka emanuje przekonanie o ścisłej korelacji między wolnością osobistą a prawem do własności. Pojęcie własności zawiera i obejmuje pojęcie wolności ${ }^{75}$. Własność jest przez niego rozumiana jako konsekwencja wolności osobowej, co skutkuje bardzo praktycznym imperatywem: „Szanuj cudzą własność”76.

Do podstawowych praw przynależnych każdej bez wyjątku osobie ludzkiej Rosmini zalicza m.in. wolność sumienia, wolność korzystania z własnych umiejętności oraz wolność zakładania stowarzyszeń, pod warunkiem że powstają one w godnych celach i chcą owe cele realizować godnymi środkami. Na poziomie życia wspólnotowego filozof z Rovereto wspomina ponadto o prawie do zawierania monogamicznego małżeństwa, prawie do ojczyzny, do narodowości i do społeczeństwa obywatelskiego ${ }^{77}$. W bogatym katalogu praw osoby ludzkiej skonstruowanym przez Błogosławionego ze Stresy znalazło się również prawo do głoszenia prawdy, a także do zgodnego z kryteriami prawdy i sprawiedliwości oceniania postępowania innych ludzi i napominania tych, którzy zbłądzili. Dopuszcza on także użycie siły celem zapewnienia sprawiedliwości. Wreszcie każdemu człowiekowi przysługuje prawo do naprawienia krzywdy poprzez sprawiedliwą karę dla tych, którzy wobec niego zawinili a także prawo do zadośćuczynienia za doznane krzywdy, jeśli jest to tylko możliwe w formie materialnej ${ }^{78}$. Za profetyczny wręcz z perspektywy XXI w. można uznać postulat, aby każdy człowiek mógł swobodnie podróżować do każdego miejsca na świecie, a także by każdy człowiek miał prawo do emigracji i azylu, którego

70 A. Rosmini, Filosofia del diritto, t. 28/A, Roma 2015, s. 419.

71 A. Rosmini, Filosofia del diritto, t. 28/A, dz. cyt., s. 420.

72 A. Rosmini, Opuscoli politici, Roma 1978, s. 94.

73 Zob. F. Petrillo, La lezione di Antonio Rosmini-Serbati. Principi giuridici fondamentali e diritti umani, Chieti 2012.

74 A. Rosmini, Scritti politici, Stresa 1997, s. 50-51.

75 A. Rosmini, Filosofia del diritto, t. 27/A, dz. cyt., s. 234.

76 A. Rosmini, Filosofia del diritto, t. 27/A, dz. cyt., s. 246.

77 A. Rosmini, Opuscoli politici, dz. cyt., s. 96.

78 A. Rosmini, Filosofia del diritto, t. 28/A, dz. cyt., s. 47-48. 
nie można by odmówić nikomu, kto się o niego ubiega ${ }^{79}$. Prawa człowieka zdaniem włoskiego filozofa powinny podlegać szczególnej ochronie ${ }^{80}$.

Przestrzenią, gdzie w praktyce weryfikuje się prawa i obowiązki człowieka, jest społeczeństwo, w którym człowiek żyje. W myśli Rosminiego osoba bezdyskusyjnie posiada prymat nad społeczeństwem, które ma wobec niej do spełnienia funkcję służebną ${ }^{81}$. W związku z tą fundamentalna tezą wspólnota nie może redukować ani tym bardziej niszczyć praw żadnego indywiduum, gdyż prawa osobowe są uprzednie i niezależne wobec społeczności obywatelskiej. Według myśli filozofa z Rovereto do symbiotycznego funkcjonowania osoby i społeczności konieczny jest nie tyle proces socjalizacji osoby, ile proces personalizacji społeczeństwa ${ }^{82}$. $Z$ tego też powodu w pismach Rosminiego bardzo trudno znaleźć pogłębioną refleksję na temat państwa. Pojęcie to niosło dla włoskiego myśliciela wiele raczej pejoratywnych konotacji ${ }^{83}$.

Człowiek według filozofa $\mathrm{z}$ Rovereto jest w pewnej mierze nakierowany na samego siebie i w swoich działaniach często zmierza do poprawy swojego subiektywnego stanu. Jednak nie można zapominać, że osoba ludzka nie jest tylko ,jakimś podmiotem" ${ }^{\prime 4}$. Dobro osoby ludzkiej dzięki aktom woli i inteligencji dostrzega ona nie w sobie samej, ale także poza sobą, przekraczając siebie i łącząc się z bytem najdoskonalszym. Doskonałość osoby nie polega na posiadaniu jakiejś części doskonałości, ale na uczestnictwie, czyli na współistnieniu w bycie najdoskonalszym ${ }^{85}$.

Opisując stosunek osoby ludzkiej do dóbr materialnych, Rosmini stosuje trzy bliskoznaczne terminy: felicità (szczęście), soddisfazione (spełnienie) i appagamento (zadowolenie). W ekonomii Roveretańczyka zadowolenie jest czymś innym niż zwykła przyjemność. Do osiągnięcia szczęścia konieczna jest świadomość zaspokojenia swoich pragnień, co jest możliwe za pomocą osądu moralnego, a do tego

79 A. Rosmini, Scritti politici, dz. cyt., s. 50.

${ }^{80} \mathrm{Na}$ straży praw człowieka ma stać konstytucja, przede wszystkim zaś opisane w niej trybunały polityczne, które mają gwarantować ochronę prawną wszystkich obywateli bez wyjątku, zwłaszcza tych najsłabszych i tych, którzy doznali niesprawiedliwości ze strony silnych. Ten najwyższy akt prawny ma również ochraniać mniejszości oraz dobro wspólne. Drugim strażnikiem praw człowieka jest według Roveretańczyka własność prywatna. Trzecim filarem tej teorii jest autonomia i wolność Kościoła. Teorie polityczne, które postulują zupełny rozdział Kościoła od państwa, Rosmini uważa za wykwit prymitywizmu politycznego. Zob. A. Rosmini, Scritti politici, dz. cyt., s. 45-49; A. Rosmini, Opuscoli politici, dz. cyt., s. 134.

81 A. Rosmini, Filosofia della politica, dz. cyt., s. 848.

${ }^{82}$ Zob. M. Cioffi, Persona e diritto in Rosmini, Roma 2005, s. 60.

83 W odróżnieniu od Hegla, twierdzącego, że państwo jest ,wielkim zorganizowanym Bogiem”, w czym Rosmini dopatrywał się wręcz przejawów idolatrii państwowej (statolatria), widział on w przesadnej ocenie roli państwa możliwość budzenia nacjonalizmu. Zob. Skrzypczak, Filozofia i teologia ..., dz. cyt., s. 175.

${ }_{84}$ Tu ponownie ma zastosowanie teoria wprzedmiotowienia.

85 A. Rosmini, Filosofia del diritto, t. 27/A, dz. cyt., s. 130. 
zdolna jest tylko osoba ludzka. Nie można zatem ograniczyć tego stanu do prostego doznawania przyjemności. „Dojrzały człowiek, jeśli podąża za jakimś dobrem, choćby tylko zmysłowym, robi to za pomocą osądu moralnego. [...] Ten, kto właściwie rozumuje, zrozumie, że człowiek, zważywszy na jego inteligencję i wolną wolę, w które jest wyposażony, nie pożąda przyjemności zmysłowych samych w sobie, ale pragnie ich jako środków do osiągnięcia stanu zadowolenia i spełnienia. Trzeba więc, aby wszelkim sposobem człowiek uważał się za zadowolonego, by mógł osiągnąć spełnienie. Jakiego środka użyje do osiągnięcia spełnienia, czy duchowego, czy materialnego, zależy od osądu wewnętrznego, co pozwoli mu osiągnąć stan pełnego zadowolenia"s6.

Pozorna absurdalność wywodów filozofa z Rovereto znika po zastosowaniu zasady naturalnego podporządkowania tego, co materialne, temu, co duchowe i intelektualne. Spełnienie, choćby jego źródłem była wielka w kategoriach wartości rzeczywistość materialna, zawsze ma charakter intelektualny ${ }^{87}$. „Cechą władz intelektualnych człowieka jest poznawanie jako właściwych sobie przedmiotów i doznań pochodzących ze zmysłów; przeciwnie natomiast: władze zmysłowe nie mogą rozpoznawać i rozumieć jako właściwych sobie przedmiotów poznania intelektualnego, ponieważ zmysły nie posiadają świadomości”"88.

Zmysły byłyby bezradne w procesie poznawczym, gdyby nie towarzyszył im intelekt. Natomiast rozumowanie ma dostęp do własnych przedmiotów poznawczych, jakimi są idee, które z kolei nie mogą być poznane tylko przez zmysły cielesne. Dlatego też zmysły, w przeciwieństwie do intelektu, nie mogą wydawać osądów moralnych, oceniać, ponieważ nie mogą w pełni poznawać ${ }^{89}$.

Roveretańczyk odróżnia jednak spełnienie od szczęścia. Pierwsze z tych pojęć odnosi się do pragnień dotyczących dóbr cząstkowych, względnych, natomiast szczęście ma za przedmiot pożądania dobro absolutne. „Szczęście jest czymś więcej niż zwykłym spełnieniem, oznacza ono spełnienie doskonalsze, w którym zadowolenie doświadczane w sposób świadomy przez człowieka ma swoje źródło w posiadaniu najwyższego i najdoskonalszego dobra" ${ }^{90}$.

Poddając krytycznej analizie utylitarystyczne teorie ekonomiczne, Rosmini bierze w obronę osobę, chroniąc ją przed błędnym kołem konsumpcjonizmu. Filozof z Rovereto stwierdza, że zachęcanie do nieustannego nabywania i konsumowania dóbr za pomocą nieskończonego pomnażania bodźców rozbudzających popyt redukuje człowieka do poszukiwacza subiektywnej przyjemności i blokuje mu dostęp do pełnego szczęścia, a nawet prowadzi do pozbawienia człowieka zadowolenia

${ }^{86}$ A. Rosmini, Filosofia della politica, dz. cyt., s. 462-463.

87 A. Rosmini, Filosofia della politica, dz. cyt., s. 462-463.

88 A. Rosmini, Filosofia della politica, dz. cyt., s. 304.

89 A.V. Castagnetta, La teoria dell'appagamento nella filosofia politica di Antonio Rosmini, w: Il pensiero di Antonio Rosmini a due secoli dalla nascita, t. 1, red. G. Beschin, A. Valle, S. Zucal, Brescia 1999, s. 561.

90 A.V. Castagnetta, La teoria ..., dz. cyt., s. 459. 
i niszczenia samej ekonomii. Dlatego proponuje wprowadzenie do ekonomii kategorii etycznych i eudajmonologicznych. Pogłębiona analiza wyborów ekonomicznych człowieka w kontekście zbliżania się od stanu spełnienia lub oddalania się od niego mogłaby stać się tamą dla wszechogarniającego konsumpcjonizmu. Ekonomia powinna uwzględniać zagadnienie wpływu dóbr materialnych na dusze ludzkie ${ }^{91}$.

Ponieważ w dziełach Rosminiego ciągle zaznacza się rozumienie człowieka nie jako jednostki, lecz jako osoby, takie filozoficzne ujęcie człowieka skutkuje adekwatnym podejściem do ekonomii. Osoba, jak zostało to wyżej wspomniane, według myśliciela z Rovereto jest bytem w relacji: w relacji do samej siebie, do świata materialnego, czyli do rzeczy, do innych osób i do Transcendencji. Prawdziwa i pełna ekonomia według Roveretańczyka zawsze musi stawiać w centrum osobę, a nie czysty zysk. Innymi słowy, w odróżnieniu od ekonomii neoklasycznej, w której celem jest osiągnięcie maksymalnych korzyści przy możliwie najniższym wkładzie własnym, dla Rosminiego celem ekonomii jest doprowadzenie człowieka do stanu spełnienia i szczęścia, które nie znajduje się w dobrach materialnych, ale w osobie ${ }^{92}$.

Podsumowując, można stwierdzić, że personalizm Rosminiego zarówno w wymiarze ontologicznym, jak i etycznym eksponuje absolutny charakter osoby ludzkiej wobec innych bytów. Jego najważniejsze źródła to triada: filozofia grecka, prawo rzymskie i Biblia jako źródło nadprzyrodzonego Objawienia. Szczególną zasługą myśliciela $\mathrm{z}$ Rovereto jest reinterpretacja sensu całego bytu w świetle personalizmu. Niewątpliwie przyczyniło się to do pogłębienia i rozwoju myśli personalistycznej w ogóle. Szczególna pozycja Rosminiego w rozwijaniu humanizmu personalistycznego wiąże się z jego odczytaniem sensu całego bytu przez pryzmat osoby. Bez wątpienia refleksja na temat osoby ludzkiej i jej istoty nie pozostawała bez wpływu na prądy filozoficzne opierające się na myśli św. Tomasza z Akwinu, czyli tomizm egzystencjalny (E. Gilson, J. Maritain) ${ }^{93}$ i personalizm chrześcijański (G. Marcel, P. Teilhard de Chardin, K. Wojtyła $)^{94}$. Dowodem tego niech będzie opinia Étienne'a Gilsona, założyciela kierunku zwanego tomizmem egzystencjalnym, który z prawdziwą estymą snuje refleksję na temat myśli antropologicznej Roveretańczyka i jego wkładu w rozwój myśli personalistycznej: „Analizując pojęcie bytu idealnego aż po jego moralne konsekwencje, Rosmini doszedł do systemu filozoficznego, który zasługuje na uwagę ze względu na swoją jedność, jak i uniwersalność. Jego etyka, podobnie jak pozostała część doktryny, charakteryzuje się dążeniem do osiągnięcia organicznej syntezy tego, co było prawdą w tradycyjnej filozofii Greków, a co zostało udoskonalone przez chrześcijańskich doktorów, z tym, co było uzasadnione w dążeniach najwybitniejszych filozofów nowożytnych. [...] Rosmini wyobraził sobie wszechświat znajdujący swój cel w moralnej doskonałości rozumnych stworzeń,

91 A. Rosmini, Filosofia della politica, dz. cyt., s. 659.

92 P.P. Ottonello, Rosmini ,, inattuale”, Venezia 2011, s. 67.

93 Zob. M. Gogacz, Tomizm egzystencjalny na tle odmian tomizmu, w: W kierunku Boga, red. B. Bejze, Warszawa 1982, s. 3-39.

94 Zob. S. Kowalczyk, Nurty personalizmu. Od Augustyna do Wojtyty, Lublin 2010. 
wszechświat porozumiewający się z Bogiem za pośrednictwem władzy poznawczej tych stworzeń - jest to zaiste wzniosła konkluzja odpowiadająca tej wzniosłej filozofii. Filozofia ta była ponadto świadectwem jednej z najpiękniejszych dusz, jakie kiedykolwiek poświęciły się poszukiwaniu chrześcijańskiej mądrości”"95.

\section{Podsumowanie}

Dokonując analizy antropologii rosminiańskiej poprzez pryzmat różnorodnych kierunków myślowych epoki, w której żył i tworzył włoski filozof, można dostrzec w jego wizji człowieka wielką teoretyczną apologię osoby. W czym przejawia się oryginalność rosminiańskiej koncepcji człowieka?

Po pierwsze, wyraża się ona w umiejętnej syntezie założeń klasycznych i nowoczesności. Nie da się prawidłowo zinterpretować personalizmu Rosminiego bez osadzenia go w jego metafizyce, tak jak w przypadku klasycznej tradycji personalizmu chrześcijańskiego. W koncepcji włoskiego myśliciela, nazywanej czasem ontologią personalistyczną, człowiek może być odczytany jako osoba jedynie „na podstawie porządku bytu" 96 .

Po wtóre, niewątpliwym dokonaniem Błogosławionego ze Stresy jest traktowanie osoby jako fundamentu budowania koncepcji polityki i prawa. Osoba dla Rosminiego nie stanowi jedynie konstruktu myślowego, lecz jawi się jako konkretne pryncypium pozwalające stworzyć głęboką, integralną wizję prawa i polityki. Antonio Rosmini ze swoim personalizmem wyprzedził epokę. Biorąc pod uwagę czas aktywności intelektualnej włoskiego filozofa, niektórzy badacze odmawiają mu prawa do zaliczenia w poczet personalistów, ponieważ ich zdaniem nurt personalistyczny w filozofii rozpoczyna się dopiero w XX w. ${ }^{97}$

O tym, jak ważną postacią w historii myśli ludzkiej, i to nie tylko dla Italii, ale dla całej cywilizacji zachodniej był bł. Antonio Rosmini, niech świadczy chociażby poniższa opinia byłego premiera i prezydenta Republiki Włoskiej, Francesca Cossigi (1928-2010): „Historia nowożytna obfituje w postacie wybitne na jakimś polu aktywności intelektualnej czy też działalności, ale żadna z tych osób nie prowadziła swojej aktywności z takim rozmachem i perfekcją jak Rosmini. W odniesieniu do średniowiecza moglibyśmy zestawić go z takimi świętymi jak Bernard, Anzelm, Bonawentura czy Tomasz z Akwinu. Ale właściwsze jeszcze będzie dostrzeżenia analogii z ojcami Kościoła z pierwszych wieków chrześcijaństwa, u których przenikliwość i spektrum zainteresowań naukowych łączą się z ewangeliczną gorliwością duszpasterską, intelektem, sercem, działalnością, wiedzą i świętością rozwiniętą aż

95 E. Gilson, T. Langan, A.A. Mauer, Historia filozofii współczesnej. Od Hegla do czasów najnowszych, Warszawa 1977, s. 230.

96 F. Evain, Notizie storico-critiche, w: A. Rosmini, Antropologia in servizio della scienza morale, Roma 1981, s. 520.

97 R. Skrzypczak, Osoba - substancja - relacja. Antonio Rosmini jako prekursor personalizmu europejskiego, „Ethos” 29 (2016), nr 4, s. 24-25. 
do granic ludzkich możliwości. Mam tutaj na myśli postacie Orygenesa, Augustyna i Ambrożego"98.

Z powodu swojej niezwykłej zdolności do budowania syntezy wiary i rozumu A. Rosmini został również przywołany na kartach papieskiej encykliki zatytułowanej właśnie Fides et ratio, mówiącej o relacji tych dwóch nierzadko przeciwstawianych sobie przejawów ludzkiej aktywności. Włoski filozof jest wymieniony wraz z takimi osobistościami świata filozofii współczesnej, jak John Henry Newman, Jacques Maritain, Étienne Gilson i Edyta Stein w świecie zachodnim, a w kręgu kultury wschodniej z uczonymi formatu Władimira S. Sołowjowa, Pawła A. Florenskiego, Piotra J. Czaadajewa czy Władimira N. Łosskiego ${ }^{99}$. Pomimo upływu czasu zarówno sama koncepcja osoby ludzkiej, jak i jej sformułowanie przez Rosminiego na drodze syntezy wiary i rozumu nie straciły nic ze swojej aktualności.

$\mathrm{W}$ dzisiejszej rzeczywistości antropologia rosminiańska z umieszczoną w jej centrum koncepcją osoby zdaje się zadziwiać swoją aktualnością. Dlatego też nie sposób wręcz polemizować z twierdzeniem włoskiego filozofa, Vittoria Possentiego, który konstatuje: „być może jak nigdy dotąd potrzeba nam odkrycia prawdziwego znaczenia pojęcia osoby, aby przedzierając się przez opary nihilizmu i funkcjonalizmu, móc zaproponować rozwiązania nowych i palących problemów współczesności" ${ }^{100}$. W dzisiejszej rzeczywistości i świecie, który coraz bardziej zatraca swoją ludzką twarz, proponowany już ponad 150 lat temu przez Rosminiego powrót do koncepcji osoby, jej ponowne odkrycie i implementacja do różnych przejawów ludzkiej aktywności intelektualnej wydaje się głosem zbyt ważnym i cennym, aby mógł zostać pominięty i przemilczany.

\section{Bibliografia}

\section{Źródla drukowane:}

Rosmini A., Antropologia in servizio della scienza morale, Roma 1981.

Rosmini A., Antropologia sopranaturale, t. 1, Roma 1983.

Rosmini A., Catechismo disposto secondo l'ordine delle idee, Roma 1898.

Rosmini A., Chiamata di tutti gli uomini alla santità in Cristo, Stresa 2007.

Rosmini A., Filosofia del diritto, t. 27/A, Roma 2014.

Rosmini A., Filosofia del diritto, t. 28/A, Roma 2015.

Rosmini A., Filosofia della politica, Roma 1997.

Rosmini A., Il principio della morale, Bari 1914.

98 F. Cossiga, Monsignor Rosmini, „30giorni” 46 (2007), z. 7, s. 2.

99 Jan Paweł II, Encyklika „Fides et ratio”. O relacjach między wiara a rozumem, Poznań 1998, nr 74.

${ }^{100}$ R. Skrzypczak, Filozofia i teologia ..., dz. cyt., s. 5. 
Rosmini A., Introduzione alla filosofia, Roma 1979.

Rosmini A., L'introduzione del Vangelo secondo Giovanni commentata, Roma 2009.

Rosmini A., Lettera ad Alessandro Manzoni, Milano, 6 febbraio 1827, Carteggio Alessandro Manzoni Antonio Rosmini, Milano 2003.

Rosmini A., Logica, t. 2, Milano 1942-1943.

Rosmini A., Opuscoli politici, Roma 1978.

Rosmini A., Psicologia. Libri dieci, Roma 1988.

Rosmini A., Saggio sulla speranza contro alcuni errori di Ugo Foscolo, Charleston 2012.

Rosmini A., Scritti politici, Stresa 1997.

Rosmini A., Storia dell'amore ricavata dalle divine Scritture, Padova 1975.

Rosmini A., Teosofia, t. 2, Roma 1999.

Rosmini A., Teosofia, t. 3, Roma 1999.

\section{Opracowania}

Addante P., Antonio Rosmini. La persona umana, malessere, diagnosi e terapia dell'amore, Reggio Calabria 2008.

Borkowski P., Bibliografia polska Antonia Rosminiego, „Człowiek w Kulturze” 18 (2006), s. 197-202.

Campanini G., Capograssi e Rosmini, w: Due convegni su Giuseppe Capograssi (Roma-Sulmona 1986), red. F. Mercadente, Milano 1990.

Castagnetta A.V., La teoria dell'appagamento nella filosofia politica di Antonio Rosmini, w: Il pensiero di Antonio Rosmini a due secoli dalla nascita, t. 1, red. G. Beschin, A. Valle, S. Zucal, Brescia 1999.

Cioffi M., Persona e diritto in Rosmini, Roma 2005.

Cossiga F., Monsignor Rosmini, „30giorni” 46 (2007), z. 7, s. 2.

Dossi M., Il santo proibito. La vita e il pensiero di Antonio Rosmini, Trento 2017.

Evain F., Notizie storico-critiche, w: A. Rosmini, Antropologia in servizio della scienza morale, Roma 1981, s. 517-530.

Gilson E., Langan T., Mauer A.A., Historia filozofii współczesnej. Od Hegla do czasów najnowszych, Warszawa 1977.

Gogacz M., Tomizm egzystencjalny na tle odmian tomizmu, w: W kierunku Boga, red. B. Bejze, Warszawa 1982, s. 3-39.

Kowalczyk S., Nurty personalizmu. Od Augustyna do Wojtyty, Lublin 2010.

Liszka P., Znaczenie terminu , subsystentność” w teologii chrześcijańskiej, „Teologia w Polsce" 12 (2018), z. 1, s. 41-54. 
Maryniarczyk A., Przygodność bytów, w: Powszechna encyklopedia filozofii, t. 8, Lublin 2007.

Mellano M.F., Anni decisivi della vita di A. Rosmini (1848-1854), Roma 1988.

Muratore U., Conoscere Rosmini. Vita, pensiero, spiritualità, Stresa 1999.

Muratore U., Idea di persona in Antonio Rosmini, w: Rosmini e Stefanini. Persona, etica, politica. Atti del Convegno, Treviso, 14-15 novembre 1997, Milano 1998, s. 37-52.

Muratore U., Manzoni e Rosmini: le ragioni di un'amicizia spirituale, „Rivista di Filosofia Neo-Scolastica” 98 (2006) nr 1, s. 131-137.

Nowicki A., Wspótczesna filozofia włoska, Warszawa 1977.

Ottonello P.P., Rosmini ,, inattuale”, Venezia 2011.

Petrillo F., La lezione di Antonio Rosmini-Serbati. Principi giuridici fondamentali e diritti umani, Chieti 2012.

Sciacca M.F., Il composto umano nel pensiero di Antonio Rosmini, „Atti del IV Convegno Nazionale di Medicina Omeopatica”, Roma, 15-18 Sett. 1969, w: M.F. Sciacca, Interpretazioni rosminiane, Milano 1971.

Sciacca M.F., Il problema dell'essenza della religione nella storiografia filosofica italiana, w: Opere complete, t. 38, Milano 1973.

Sgroi A., La „,corporalità” secondo Rosmini, „Bioetica e Cultura” 21 (2012), nr 1, s. $71-80$.

Skrzypczak R., Filozofia i teologia osoby bł. Antoniego Rosminiego - ojca personalizmu europejskiego, Kraków 2013.

Skrzypczak R., Osoba - substancja - relacja. Antonio Rosmini jako prekursor personalizmu europejskiego, „Ethos” 29 (2016), nr 4, s. 23-41.

Tadini S.F., Il problema di Dio nella metafisica rosminiana, Milano 2015.

Wierzbicki A., Osoba jest prawem. Komentarz do Antonio Rosminiego personalistycznej koncepcji prawa, „Ethos” 12 (1999), nr 1-2, s. 95-108.

Wojtyła K., ,,Osoba i czyn” oraz inne studia antropologiczne, Lublin 2000.

Wojtyła K., Miłość i odpowiedzialność, Lublin 2001.

Wroczyński K., Człowiek, osoba i prawo w świetle definicji Antonia Rosminiego, „Człowiek w Kulturze” 18 (2006), s. 97-111.

Zama R., La persona e la libertà in Rosmini, Stresa 2006.

\section{Streszczenie}

Bł. ks. Antonio Rosmini (1797-1855) to niezwykle wszechstronny i płodny pisarsko myśliciel włoski. Jego spuścizna naukowa obejmuje prawie 100 książek z różnych dziedzin: od filozofii poprzez teologię aż po nauki polityczne. Był niezrozumiany 
przez swoje pokolenie. Jego dwie prace: O pięciu ranach Kościoła Świętego (Delle cinque piaghe della santa Chiesa) oraz Konstytucja wedhug sprawiedliwości spotecznej (La Costituzione secondo la giustizia sociale) zostały wpisane na Indeks ksiag zakazanych. Po wielu latach zrehabilitowany, został ogłoszony błogosławionym w $2007 \mathrm{r}$.

Domeną jego zainteresowań była filozofia, a szczególnie metafizyka i antropologia. Dzięki stworzeniu spójnej i oryginalnej koncepcji osoby jest nazywany ojcem europejskiego personalizmu. Niniejszy artykuł jest próbą przedstawienia rosminiańskiej wizji osoby ze szczególnym zwróceniem uwagi na ontologiczne podstawy jego teorii.

Słowa klucze: Rosmini, filozofia, osoba, personalizm

\section{The Ontological Basis of the Anthropology of Bl. Antonio Rosmini}

\section{Summary}

Blessed Fr. Antonio Rosmini (1797-1855), was an extremely versatile and prolific Italian thinker. His scientific legacy includes nearly 100 books in various fields: from Philosophy and Theology to Political Science. He was misunderstood by his generation. His two works: The Five Wounds of the Church (Delle cinque piaghe della santa Chiesa) and The Constitution according to Social Justice (La Costituzione secondo la giustizia sociale) were both included in The Index of Prohibited Books. Rehabilitated after many years, he was proclaimed Blessed in 2007.

His main interest was philosophy, especially metaphysics and anthropology. By creating a coherent and original concept of the person, he is called the father of European Personalism. This article is an attempt to present Rosmini's vision of the person with particular attention to the ontological foundations of his theory.

Key words: Rosmini, philosophy, person, Personalism 